\title{
Continuity and Pragmatism: How Chinese State-Owned Banks adapted to Hong Kong's Free Market (1949-1978)
}

This is an Accepted Manuscript of an article published by Taylor \& Francis in Journal of Contemporary Asia, 2015

Available online: http://dx.doi.org/10.1080/00472336.2015.1123283

\section{Damian Tobin}

Department of Financial and Management Studies, School of Oriental and African Studies, London, UK

Email: dt29@soas.ac.uk

Correspondence address: Department of Financial and Management Studies, School of Oriental and African Studies, Thornhaugh Street, Russell Square, London WC1H 0XG, UK

\begin{abstract}
One of the puzzling features of China's post-1978 economic reforms is how quickly its enterprises adapted to the new business environment. An insight into this puzzle is provided by Chinese state-owned banks in Hong Kong. From 1949-78 these banks, led by the Bank of China, represented China's primary financial interface with the outside world. What distinguished the management of these banks from their peers was their loyalty to communist values. Yet, despite Mao Zedong's anti-imperialist anti-capitalist ideology, the Bank of China demonstrated extraordinary business pragmatism in its engagement with the international financial system. It also exemplified a high level of management continuity which enabled it to see beyond a volatile and often hostile political environment. The paper shows that the post-1978 retreat from ideology and its replacement with commercial incentives proved costly in terms of professional standards. A homogenisation of bank management also made it more difficult to recruit senior management whose loyalty to the Communist Party could be assumed. These findings highlight the importance of rule variation in explaining international differences in management behaviour. More generally the paper shows the long term importance of Hong Kong's role as an internationalising force for China's business and financial sectors.
\end{abstract}

Key Words: Hong Kong, Banks, Bank of China, Ethics, International Trade, Renminbi Internationalisation 
China's reintegration into the global economy in the early 1970s coincided with major upheavals in international finance including the collapse of the Bretton Woods system and the emergence of large money-centre banks. Despite their communist backgrounds, overseas state banks from the People's Republic of China (PRC) in Hong Kong proved remarkably adept at dealing with these challenges. Not only did PRC banks in the then Colony anticipate these changes, rapidly expanding their branch numbers, but they also made the first efforts at internationalising the Chinese currency. Recently released archives indicate that by the 1980s the PRC's leadership had developed an in-depth understanding of the relationship between Hong Kong's financial stability and the presence of large international banks (South China Morning Post, hereafter, SCMP, January 7, 2014). This highlights an interesting puzzle, namely why, given Mao Zedong's apparently uncompromising anti-imperialist and anticapitalist ideology, were these state-owned banks allowed to conform to what were colonial and capitalist banking practices. It also raises the question as to how this apparent contradiction was resolved in the bank's operations and management; and why did the rejection of this ideology after 1978 not lead to a faster opening up of the Mainland's financial sector and a greater role for banks in financing the PRC's post-1978 modernisation? In exploring these questions, this article focuses on the Hong Kong operations of the Bank of China (BOC) during the period 1949-78. As the bank responsible for co-ordinating the PRC's foreign exchange earnings, the BOC offers a fascinating insight into how China's pre-reform economy managed the link between export competitiveness and hard currency earnings and the apparent ease at which this role later gave way to commercial considerations.

The establishment of the PRC in 1949 signalled a new departure in China's development and the beginning of one of its most chaotic periods, characterised by both internal turmoil (post-Great Leap famine 1959-61, Cultural Revolution 1966-76) and external isolation (Sino-Soviet split in 1960 and US embargo in the years 1950-71). International 
isolation severely restricted the opportunities for international trade and as a consequence the PRC suffered from an acute shortage of foreign exchange. The ending of the US embargo in 1972 and the launching of "open door" policies in 1978 resulted in the shortage of foreign exchange being replaced by a surplus of FDI. As the PRC's specialised foreign exchange bank, the BOC and its overseas branches played a crucial role in mitigating foreign exchange shortage and adapting to changes in the international economy. Founded in 1912 as an official bank following the reorganisation of the Daqing Bank (大庆银行), the BOC had considerable exposure to international banking practices before 1949. It operated as a private bank from 1916 to 1935 (Cheng, 2003). On the March 12, 1950, a CCP decree effectively signalled the communist takeover of the bank's government shares (Cheng, 1954). After 1949 the BOC and its overseas branches operated under a system of centralised control and unified management of foreign exchange, explicitly designed to ensure the supply of funds for socialist construction (Renmin Ribao, December 30, 1980). Operating in Hong Kong's capitalist system placed bank management beyond the direct reach of the ideological campaigns and political disruption that characterised much of the period 1966-76 on the Mainland. It also placed the bank to the fore of developments in the international financial system. The effects of these events were particularly pronounced in the Hong Kong operations of the BOC. Even before the "open-door" policies, the bank had begun to reflect changes taking place in international banking, expanding its local branch presence and deposit base and making the first efforts to internationalise the Renminbi (RMB).

The ability to anticipate and adapt to developments in international finance offers a unique insight into the effects of management agency and cross-border rule variation in banking. Both factors have been identified as significant in understanding how organisations respond to variations in their environment. Casson (2010) argues that continuity and changes in key management personnel are central to understanding how organisations adapt their 
strategies. Penrose (1954) points out that while the identity and survival of a firm has much to do with legal rules, the firm cannot survive the dispersal of its assets and personnel. Baumol (1990) proposed that it is variations in the rules of the game rather than the supply of entrepreneurs, which explain differences in how economies allocate the rewards of entrepreneurship. The effects of the transition to communist control in 1949 and the retreat from Maoist ideology in the late 1970s offer a unique test of these contentions in banking. The study also provides further evidence on the complex historical foundations of Hong Kong's role as an internationalising force for Chinese businesses. Hong Kong became the first location for internationalising the RMB, while the BOC became the main clearing bank for the overseas settlement of RMB currency in 2003 and the main intermediary between Hong Kong banks and the People's Bank of China. This study draws on unpublished archival sources to illustrate both the pragmatism and continuity that characterised the PRC's relationship with Hong Kong, thus contributing to a large existing literature on the economic and business ties between Hong Kong and China and Hong Kong's emergence as a financial centre (Jao, 1974, 1983; Goodstadt, 2005, 2007; Schenk, 2002, 2009).

The rest of the article is structured as follows. The next section describes Hong Kong's role in mitigating the severe shortage of foreign exchange faced by the PRC. This is followed by a section that outlines how the Hong Kong branch of the BOC resolved the ethical issues surrounding its participation in capitalist money markets. The final substantive section advances the possibility that the operations of the BOC reflected a deeper pragmatism in the PRCs approach to the international economy as well as the willingness of the CCP to relax its ideological stance when faced with crisis. It also speculates that the extension of pragmatism nationwide after 1978 alongside the emergence of a new generation management, whose views on capitalism were no longer constrained by Maoist ideology, meant that PRC banks in Hong Kong were no longer ideologically different from their peers. Despite this, the 
article concludes that the strengthening of Hong Kong's banking regulations since the mid1960s have had a positive effect in mitigating the contagion of the non-performing loan problem to the BOC's Hong Kong operations.

\section{PRC BANKS IN HONG KONG}

While a substantial body of research inspired by the economist Joseph Schumpeter has proposed an association between a developed financial system and economic growth; it is significant that China's post-1978 growth appears at odds with what is often referred to as the "finance and growth" consensus (Levine, 1997; Allen et al, 2005). Instead of being Schumpeterian drivers of growth, China's state-owned banks shouldered much of the cost of economic reforms (Hale and Long, 2010). This apparent contradiction is even more interesting when compared to the history of PRC banks in Hong Kong and their role in financing the PRC's modernisation agenda during the 1960s and 1970s. Drawing on theories of agency and institutional change, this section outlines how such issues as domestic shortage and changing attitudes to foreign capital influenced the activities of the PRC's Hong Kong banks.

\section{Banks, Management Agency and Rule Variation}

The focus of this article on overseas banking is deliberate. Recently the foreign exchange operations of large global banks have come under scrutiny following charges of money laundering, drug trafficking and terrorist financing (US Homeland Securities and Government Affairs Committee, 2012). It has been shown that the trading arms of large banks tend to be those least constrained by the bank's normal accountability and remuneration structures (Cetina and Bruegger, 2002). The discretion afforded to currency traders gives them significant agency in the sense that their interests are often not aligned 
with board level views on the bank's ethics and social responsibilities. In theory, a similar discretion would have created incentives for opportunistic behaviour among the management of the PRC's overseas banks. In practice it was assumed that all managers, even those operating beyond the reach of the PRC's mass rallies, public criticism sessions and detention on ideological grounds - an immunity Hong Kong offered - would voluntarily act in the interests of the PRC.

Agency Theory also offers insights into the intermediary functions of financial institutions. Financial institutions are thought to improve the efficiency of resource allocation by screening borrowers and monitoring their behaviour (Stiglitz, 1989). This recognises that firm management are not homogenous and could behave opportunistically. Under central planning, the problem of opportunism was essentially eliminated since most loans were for working capital rather than investment purposes and the intermediary role of banks "was circumscribed and their disciplinary role non-existent" (Lardy 1998, 61). Operating in overseas capitalist markets meant that the Hong Kong branch of the BOC and its "sister banks" were an exception to this. The latter included the Bank of Communications, China \& South Sea, China State, Kincheng, Kwangtung, Nanyang, National Commercial, Po Sang, Sin Hua, Young Brothers and Yien Yieh. The BOC also had branches in Singapore, Rangoon, Penang, Jakarta, Calcutta and Karachi though the volume of sterling purchased in these markets was far smaller than in Hong Kong.

Within this group of Hong Kong-based "sister" banks there was also significant variation. While state banks such as the BOC, the Bank of Communications and Nanyang Bank were involved in the currency off-take and remittances businesses, others such as Yien Yieh, Sin Hua and the Young Brothers had strong private sector origins and were involved in financing local Chinese businesses. Po Sang Bank was unique in the sense that it was focused on gold trading. These banks were one constituent in a small group of PRC-owned 
conglomerates designed to further the PRC's trade and cultural interests in Hong Kong. They included the China Resource Company, the China Merchant's Company, China Travel Services and the Xinhua News Agency. The investments of these conglomerates were conservative and largely restricted to handling currency remittances, distributing PRC products to Chinese-controlled stores, shipping goods and providing travel services (Sung, 2005: 123). They also kept a relatively low profile and a comparative study on the PRC and Hong Kong indicate comparatively low levels of official corruption within Mainland organisations in Hong Kong during the pre-1978 era (Manion, 2004).

The decision in 1978 to switch to a growth strategy that was based on pragmatic as opposed to ideological criteria had the objective of removing the institutional rules that inhibited the entrepreneurial and competitive spirit of management (Deng, 1978). The rejection of ideology was signalled in the simple but powerful slogan "practice is the sole criterion for testing truth.” The slogan's apparent common sense ensured its rapid acceptance. Its appeal reflected a widespread frustration with the failure of officials to give up control over business activities (Zhang 1984). However the sudden undermining in 1978 of an ideology based hitherto almost entirely on a self-denying Puritanism was greeted with shock and disillusionment by many of the PRC's overseas agencies, particularly in those whose employees had made large personal sacrifices during the Cultural Revolution. It also witnessed the emergence of a new generation of management whose views on commercial lending were no longer constrained by Maoist ideology. This exposed a mismatch between centralised Leninist control structures and the demands for a more efficient allocation of resources (Heilmann, 2005). From this perspective the switch to pragmatism offers a unique test of Baumol's (1990) contention that it is variations in rules from one period to another that shape the reward structure of society. This contention is based on the view that the waning of 
entrepreneurial spirit provides an insufficient explanation for productivity problems and provides "no guidance on how to reawaken that spirit once it has lagged" (Baumol 1990, 894).

\section{The Pre Reform Banking System and Foreign Exchange}

Although the PRC's simplified mono-banking structure effectively internalised market risk, this did not remove the need for foreign currency in balancing mismatches in the central plan. Neither did it obscure the fact that involvement in Hong Kong's foreign exchange market presented ethical dilemmas for banks that claimed to be operating under the banner of Marxism-Leninism-Mao Zedong Thought. The currency trading operations of PRC banks were regarded as a special case of capitalism. Their ethical integrity was therefore crucial, as failure would have exacerbated China's shortage of foreign exchange.

Assessing the role of foreign exchange in funding domestic loans and investment is complex. As a balancing item, Chinese foreign exchange earnings were small and subject to domestic production constraints. For example, under the Second Five-Year Plan (1958-62) domestic bank loans increased from RMB 47.7 billion in 1958 to 96.9 billion by 1960 (XZWNTZH, Table A54 and A59). This reflected the policy of encouraging banks to supply enterprises with as much working capital as they needed under the Great Leap Forward's drive for industrialisation (Donnithorne, 1967). However a shortfall in exports from 1959 to 1962 as the economy faced an agricultural disaster, resulted in an outflow of foreign exchange. This was reversed from 1963 to 1965 as officials sought to restore order to the economy and exports increased. Although the Cultural Revolution interrupted the growth in international trade, domestic bank lending continued to increase as did bank's foreign exchange holdings. In 1969 China purchased some RMB 1.63 billion of foreign exchange compared to RMB 0.98 billion in 1966 (XZWNTZH, Table A59). 
By 1970 exports were once again under pressure and foreign exchange reserves had fallen to US $\$ 0.191$ billion from $\$ 0.498$ billion in 1969. The "resurrection" of the industrial export sector in 1971 by Premier Zhou Enlai effectively guaranteed financing for a return to import substitution policies underpinning the Four Modernisations (Reardon, 2002). This was a modernisation agenda first set out by Zhou in 1954. In 1972 following the normalisation of trading relations with the US, the PRC began to use a combination of export promotion and short-term foreign exchange loans to finance the purchase of foreign plant and machinery (Reardon, 2002). These developments were interrupted by anti-rightist attacks on export promotion policies. Yet despite these setbacks it was clear that the ideological opposition to international markets and foreign debt had begun to irreversibly soften.

\section{Hong Kong: The PRC's Financial Interface}

Given the political chaos, economic disasters and international isolation faced by the PRC during the period 1949-1978, it would have been extremely difficult to finance its domestic modernisation agenda without access to Hong Kong's foreign exchange market. In 1959, just before the Sino-Soviet crisis, exports for Hong Kong accounted for $11.1 \%$ of China's total exports; by 1969 at the height of the Cultural Revolution this figure had increased to $20.4 \%$ (Hong Kong Review of Overseas Trade, 1978). Hong Kong, a British colony until 1997, experienced extraordinary growth under a free port, free currency economic model. This model was reflected in a diverse banking system, which included a mix of foreign, local and Mainland banks. For example, in December 1966, foreign banks accounted for $58 \%$ of total deposits, local Chinese banks $27.3 \%$ of deposits and Mainland banks $14.7 \%$ of deposits (Hong Kong Records Service, hereafter, HKRS, 163-1-3274). Hong Kong also suffered from corruption, which was tolerated until 1974. Its banking regulations were largely unenforced from 1948 to 1964 and not comprehensively and effectively extended to the rest of the 
financial sector until the mid-1980s. This had serious consequences for the stability of financial institutions, particularly in the secondary market and from 1970 to 1982 the colony experienced a growth of unregulated non-bank financials and repeated cycles of bubble markets, bank runs, and scandals that only ended in 1985. Concealed in this however was a general improvement in the ethical and professional standards of banks, starting with the 1964 Banking Ordinance and the establishment of the Independent Commission Against Corruption in 1974. This more general improvement meant that by 1978 the ethical practices of Chinese state-owned banks were no longer a great exception.

From the PRC's perspective, Hong Kong's advantage for much of the period 1949-78 was the stable access it provided to international trade (Goodstadt, 2005). Much of the PRC's exports to Hong Kong during this period were subsequently re-exported to Japan, Indonesia and Singapore. Hong Kong also offered an ear on the outside world. In 1969 Zhou Enlai ordered the Xinhua News Agency and the BOC to study Hong Kong's economic and political institutions in order to gain a better understanding of the international economic situation (Reardon, 2002). PRC officials also developed an astute knowledge of the unstable international economy and the problems facing Western banks during this period. This was illustrated in coverage of the economic crisis in the 1970s and the PRC's ability to apply hard economic principles to monetary policy decisions (Xinhua, October 24, 1974). A substantial proportion of the PRCs foreign exchange purchases were funded from the deposits held by the BOC in Hong Kong, a move that vastly increased China's ability to import plant and machinery (Tobin, 2011). The following section examines the puzzle of how the BOC coordinated this activity without compromising on the CCP's ideological views on foreign trade. 


\section{THE BANK OF CHINA IN HONG KONG}

As the primary interface set up to meet China's foreign exchange requirements, the Hong Kong branch of the BOC had the sole objective of implementing the guiding principles of national development as propounded by Mao Zedong (Chou, 1978). Its main customers during this period were PRC trading companies, Chinese businesses in Hong Kong, small depositors and those sending remittances to Mainland China. In stark contrast to the post1978 era, the bank largely avoided any involvement in speculative property development or other commercial activities. The aversion to commercial banking activities did not hinder its ability to provide innovative banking solutions in the area of foreign exchange. Assessing the BOC's Hong Kong operations presents significant challenges. Like many banks the BOC had a tendency for secrecy. It was also a politically sensitive institution. In Hong Kong the bank served as a rallying point for supporters of the CCP and documents show that the police were typically suspicious of efforts by the bank to construct worker housing in strategically sensitive locations. ${ }^{1}$ This section draws on archive material from the Hong Kong Public Records Office and the National Archives of Singapore. Recognising that these sources may contain certain biases, their accounts are verified and contextualised by drawing on authoritative economic studies on Hong Kong and the PRC during this period as well as media and other sources.

\section{Balancing Ideological Beliefs and Shortage}

China's central plan was built on predictability of supply. In theory, the circulation of money was equivalent to the circulation of goods, while export earnings guaranteed a balance between foreign exchange income and expenditure. In practice the PRC experienced routine periods of domestic austerity and hard currency shortage. Following the Korean War (195053) the US froze many of the PRC's external assets and as a result the PRC held a large 
proportion of foreign reserves in sterling (Donnithorne, 1967) By the mid-1970s there were widespread rumours regarding the perilous state of China's foreign exchange reserves and the possibility that the PRC would be unable to pay for its imports (Kyodo, January 20, 1975). The main objective of the Hong Kong branch of the BOC was to co-ordinate foreign exchange earnings thereby helping to mitigate domestic shortage. In doing so it showed an impressive ability to work with foreign banks and local authorities to maintain access to what was a vital source of hard currency.

Such a role created an ethical dilemma for the BOC. The CCP's ideological distaste for capitalism included an opposition to international loan and money market finance, which it viewed as exploitative (Xinhua, March 1, 1976). Therefore involvement in capitalist money markets meant the BOC would have risked being labelled a supporter of colonial interests. The potential problems this could create were illustrated by the Chinese-owned Far East Bank. Although not a state-owned bank, the Far East Bank had been praised for facilitating cross-border remittances. However the bank's manager, Deacon Chiu (an emigrant from Shanghai who later became a major investor in the region), was accused in 1967 of openly supporting the colonial authorities in perpetrating atrocities against the Chinese people (HKRS 934-7-104). ${ }^{2}$ The penalty for such activities was a severing of links with other PRC banks in the Colony. Isolating the bank also proved to be politically convenient. During Hong Kong's 1965 banking crisis, HSBC were required to publically guarantee the bank's deposits; a guarantee that was only revoked in 1969 when the bank was taken over by the First National City Bank (Jao, 1974: 249). Such events would simply have confirmed the communist view that capitalism itself was unstable.

The BOC reconciled its ideological stance on capitalism and working with international financial institutions by maintaining a highly conservative and liquid balance sheet. As Figure 1 shows, this distinguished the BOC from other international banks with 
operations in Hong Kong such as the Hong Kong and Shanghai Banking Corporation, Bank of America and First National City Bank as well as such Hong Kong banks as Hang Seng and the Bank of East Asia. It also distinguished the BOC from its sister state-owned banks, many of whom had a greater involvement in financing local Chinese businesses. The BOC's large balance sheet could be explained by the fact that all balances were essentially the property of the PRC and were credited to head office in Beijing every third day. These funds were to be used by the Ministry of Finance in the national interest. The low level of deposits employed in Hong Kong was cited as a source of frustration by the colonial administration, which relied on the integrity of the Chinese banks in conducting sterling transactions. ${ }^{3}$

\section{Figure 1. Ratio of Advances to Deposits in Hong Kong Banks}

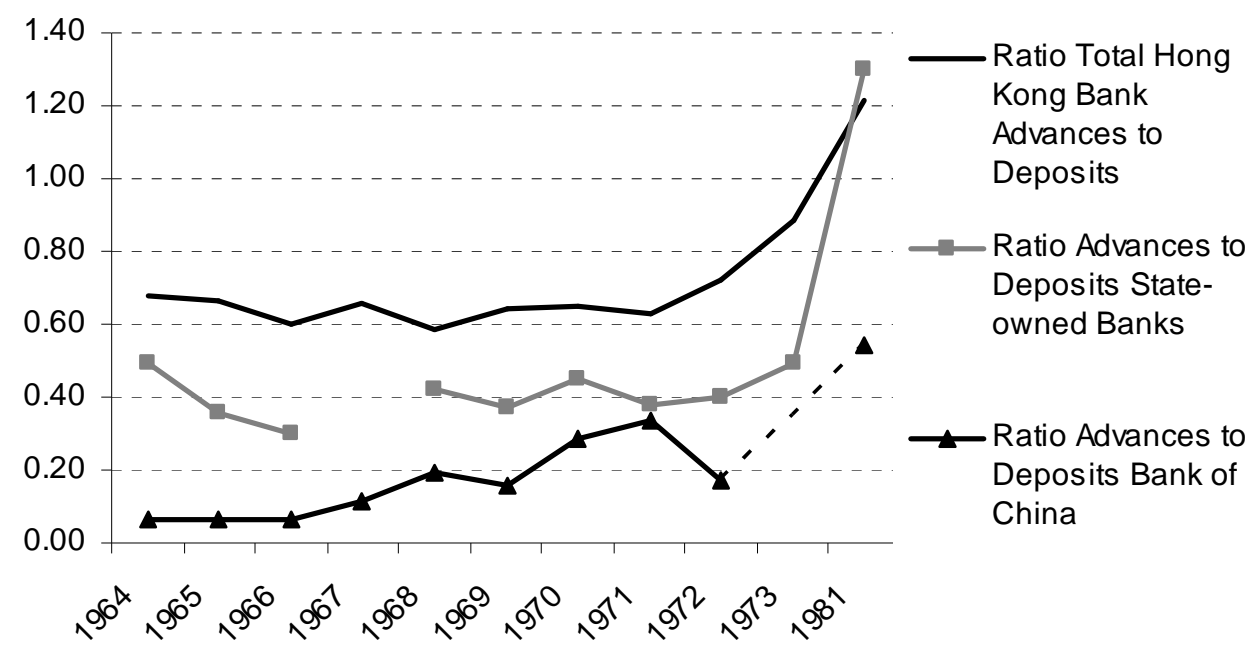

Source: Data for 1964-68 were derived from the statistical returns from licensed banks collected monthly by the Banking Commission and preserved in the following Hong Kong Public Records Service files: HKRS163-1-3273 "Banking Statistics Various 1965." HKRS163-1-3274 “Banking Statistics Various - 1966," HKRS163-1-3275 "Banking Statistics Various - 1967,” HKRS163-1-3276 “Banking Statistics Various.”

Despite the BOC's overriding objective of operating in the national interest, accounts of the development of Hong Kong's banking sector indicate a remarkable level of cooperation with international banks. Goodstadt (2007: 89) argues that the paradoxical results 
of punitive US measures, which also targeted HSBC and other banks operating in Hong Kong, was to make it easier for these banks to foster relationships with Chinese state-owned banks. During 1967 the demand from the BOC in Hong Kong was such that the Hong Kong and Shanghai Banking Corporation had to buy US dollars, to convert to sterling and negotiate an emergency government issue (Schenk, 2009a: 113). Archival correspondence show that cooperation between the BOC, commercial banks such as Chartered Bank and the Hong Kong and Shanghai Banking Corporation, and the Bank of England, were cited by colonial officials as being a highly useful source of information on the PRC's financial policies. ${ }^{4}$ For its part, the BOC from 1955 onwards agreed to channel enough business through the Shanghai offices of the Hong Kong and Shanghai Banking Corporation and Chartered Bank to cover their overheads (Schenk, 2009b). Such co-operation also extended to the political level. An assistant manager at the BOC's Hong Kong branch K.C. Jay facilitated direct communication between the Hong Kong government and Zhou Enlai during the height of the Cultural Revolution (SCMP, April 17, 2006).

It is even more remarkable that these events took place against a background of strenuous efforts on behalf of the US and UK governments to close down the sterling trade with China (Tobin, 2011). This trade was central to the BOC's mission of solving the PRC's foreign exchange shortage through its involvement in the sterling off-take business. The sterling off-take refers to the sterling that authorised PRC banks purchased in Hong Kong's free market. Table 1 show how the bank responded to worsening economic conditions in China by rapidly increasing its purchases of sterling. Greater trade with non-communist countries after 1960 required greater access to hard currency. Increases in imports of grain and fertiliser following the repositioning of agriculture in the aftermath of the Great Leap were reflected in the BOC's sterling purchases from 1961 onwards. Increased sterling purchases helped mitigate losses from the collapse in exports. The data in Table 1 also show 
that one of the more paradoxical effects of the Cultural Revolution was to further increase reliance on foreign exchange from Hong Kong. A devaluation of the Pound Sterling and Hong Kong Dollar in November 1967 was offset by a revaluation of the RMB and an increase in the price of PRC products. This was implemented by the BOC, effectively compensating for any loss in foreign exchange earnings caused by Sterling's devaluation. These events illustrate the important role the BOC played in maintaining foreign exchange balances during the period 1967-70 when the PRC's exports were under considerable pressure.

Although foreign exchange dealings were the less predictable item in the state plan and the only part of the plan subject to market prices, there is no evidence in either the public record or media of any cases of impropriety on behalf of PRC banks in Hong Kong during this period. ${ }^{5}$ The banks were also compliant with requests by the colonial administration for banking statistics, despite official doubts about their willingness to supply such data (HKRS 163-1-623). This narrative is also consistent with the experience of other overseas branches such as in Singapore where the colonial authorities sought on a number of occasions to close the BOC branch. On one occasion in January 1958 it was noted that although the BOC was suspected of financing of subversive (meaning communist) organisations, no evidence of professional malpractice could be found and the suspicions were thought to have been politically motivated. ${ }^{6}$ In any event commercial considerations tended to override politics. Officials expressed concern that any move against the BOC might have an adverse effect on the relaxed attitude taken by the PRC towards UK banks operating in China and the resulting benefits that accrued to UK trade. 
Table 1. PRC Sterling purchases and PRC Exports to Hong Kong (1955-72)

\begin{tabular}{|c|c|c|c|c|c|}
\hline Year & $\begin{array}{l}\text { BOC Hong } \\
\text { Kong }\end{array}$ & $\begin{array}{l}\text { Total PRC } \\
\text { banks } \\
\text { Hong Kong }\end{array}$ & $\begin{array}{l}\text { BOC Hong } \\
\text { Kong } \\
\text { Deposits } \\
\text { (HK\$mill) }\end{array}$ & $\begin{array}{l}\text { PRC } \\
\text { Exports to } \\
\text { Hong Kong } \\
\text { (HK\$mill) }\end{array}$ & Notable Events and Trade Data \\
\hline 1955 & $35,245,000^{\mathrm{a}}$ & - & - & 898 & $\begin{array}{l}\text { Policy of 'Leaning to One Side' } \\
\text { Trade with non-communist countries } \\
26 \% \text { of total trade }\end{array}$ \\
\hline 1956 & - & - & - & 1,038 & $\begin{array}{l}\text { Trade with non-communist countries } \\
34 \% \text { of total trade }\end{array}$ \\
\hline 1957 & $41,000,000^{\mathrm{b}}$ & $90,800,000$ & - & 1,131 & $\begin{array}{l}\text { Gradual relaxation of trade restrictions } \\
\text { with non-communist world (excl. USA) } \\
\text { which accounts for approx. } 36 \% \text { of } \\
\text { total trade }\end{array}$ \\
\hline 1958 & $84,900,000$ & $95,200,000$ & - & 1,397 & Great Leap Forward \\
\hline 1959 & $74,986,954$ & $87,066,954$ & - & 1,034 & $\begin{array}{l}\text { Trade with non-communist world } 31 \% \\
\text { of total trade }\end{array}$ \\
\hline 1960 & $77,550,000$ & $94,100,000$ & - & 1,185 & $\begin{array}{l}\text { Beginning of Sino-Soviet Split } \\
\text { PRC Exports: } 6.63 \text { bn Yuan }\end{array}$ \\
\hline 1961 & $66,800,000$ & $84,200,000$ & - & 1,029 & $\begin{array}{l}\text { Beginning of grain \& fertilizer imports } \\
\text { from West (excl USA) }\end{array}$ \\
\hline 1962 & $84,700,000$ & $105,680,000$ & - & 1,215 & PRC Exports: 4.71bn Yuan \\
\hline 1963 & $113,200,000$ & $138,590,000$ & - & 1,488 & $\begin{array}{l}\text { Plant \& Machinery imports from Japan } \\
\text { \& Europe }\end{array}$ \\
\hline 1964 & $161,300,000$ & $186,330,000$ & 124 & 1,971 & PRC Exports 5.54bn Yuan \\
\hline 1965 & $199,900,000$ & $227,440,000$ & 165 & 2,322 & $\begin{array}{l}\text { Non-communist countries account for } \\
\text { approx. } 70 \% \text { of total trade }\end{array}$ \\
\hline 1966 & - & - & 290 & 2,783 & $\begin{array}{l}\text { Cultural Revolution begins } \\
\text { PRC Exports: } 6.6 \text { bn Yuan }\end{array}$ \\
\hline 1967 & - & - & 188 & 2,299 & $\begin{array}{l}\text { Severe industrial disruption on } \\
\text { Mainland } \\
\text { Revaluation of RMB against HK\$ }\end{array}$ \\
\hline 1968 & - & - & 189 & 2,446 & PRC Exports fall to 5.76bn Yuan \\
\hline 1969 & - & - & 214 & 2,717 & $\begin{array}{l}\text { Ending of Radical phase of Cultural } \\
\text { Revolution }\end{array}$ \\
\hline 1970 & - & - & 208 & 2,846 & PRC exports fall to 5.68bn Yuan \\
\hline 1971 & - & - & 204 & 3,348 & Resurrection of Export Sector \\
\hline 1972 & - & - & 202 & 3,868 & US\$ Embargo ends \\
\hline
\end{tabular}

Notes:

${ }^{a}$ Figures for 1955 refers to sterling purchases between March and September

${ }^{\mathrm{b}}$ Figures for 1957 refer to sterling purchase between July and December

Sources: Statistics derived from: HKRS163-1-2055 (Exchange Control: Monthly statistics showing Chinese purchase of sterling and Chinese inward remittances), HKRS163-1-3274, HKRS163-1-3275 HKRS163-1-3276; and Xin Zhongguo Wushi Nian Tongji Ziliao Huibian

The pay-off from the BOC's ideological compromise was access to hard currency.

Only a small proportion of the bank's deposit base was employed in Hong Kong. It was not in the business of maximising commercial lending and maintained a deposit reserve far in excess of its Hong Kong counterparts. The evidence for this is to be found in its practice of 
minimising the ratio of advances to deposits (see Figure 1). This lessened the potential for profits, but could be justified as reducing the PRC's involvement in the more unacceptable and risky aspects of capitalist banking. In an era when a bank's capital was not guaranteed and the international political environment was volatile, easy access to deposits would have been a top priority.

\section{A unique generation of management}

The nationalisation of the BOC after the CCP came to power in 1949 meant that its overseas management had a choice; either to stay within the now communist bank, or leave and pursue commercial opportunities elsewhere. Many of the bank's overseas branches choose to operate under the departing Kuomintang government. Given their private sector origins, a fascinating feature of the management who chose to stay was their willingness to support and work with the new Communist regime, even if it meant loss of privileges and lifestyle (Far Eastern Economic Review, 1949: 702). This generation had first-hand knowledge of how corruption had destroyed the credibility of the pre-1949 government. The decision to remain was therefore as much about lifestyle choice as anything else. As part of the political and business elite, the bank's management were highly experienced in the PRC's foreign trade and the intricacies of its political system.

The decision to remain within the bank by free choice is significant in terms of understanding both the degree of agency granted to overseas bank management and the level of operational continuity that the BOC enjoyed. Although operating in a capitalist economy, the bank, even before 1949, was organised along the lines of a typical Danwei. These work units placed a high emphasis on discipline and efficiency (Yeh, 1995). For example, in Hong Kong the BOC had a preference for housing workers in communal blocks (HKRS 156-14850) It is unsurprising, therefore, that overseas CCP organisations were staffed by those 
loyal to the communist cause (Klein, 1960). The BOC in Hong Kong faced the challenge of ensuring that staff were politically "reliable" in a colony whose administration regarded PRC organisations as potentially subversive and therefore as targets for surveillance. The Hong Kong police were typically wary of efforts by the BOC to construct communal blocks (HKRS 156-1-4850). Thus, the bank sought to employ managerial staff whose commitment to the CCP had been tested in the struggles before it came to power. The rank and file were recruited as far as possible from families who had been active in CCP-led trade unions or attended CCP-controlled schools in Hong Kong.

Although the BOC's Hong Kong management kept a low public profile and are now deceased, the available backgrounds of some of its senior management provide an insight into how they reconciled loyalty to $\mathrm{CCP}$ values with capitalism. The BOC's Hong Kong manager for much of this period was Zheng Tieru (郑鐵如 also known in Hong Kong as Shou J Chen). A plaque honouring Zheng's contribution is located at the base of the original BOC building in Hong Kong. Zheng first joined the Shantou branch of the BOC in eastern Guangdong Province in 1922. He successfully managed the Hong Kong operations of the BOC prior to 1949. Official correspondence between Zheng and the Hong Kong government in 1948 indicate Zheng's efforts to ensure the BOC's Hong Kong branch made a smooth transition to state-ownership under the CCP after 1949 (HKRS 163-1-735). Fearful that political events on the Mainland, which included the distinct possibility of bank nationalisation and the fact that Beijing required every cent of foreign exchange it could get its hands on, would endanger his efforts to construct a new bank building in Hong Kong, Zheng asked the Hong Kong Governor to consider a brief postponement of the plans. Zheng argued that if the plan was left quiet for a year or so, the political agitation on the Mainland would eventually blow over and he could get on with building his bank. 
This ability to maintain management continuity and see beyond potentially destabilising events was to characterise the bank's management over the following decades. Although Zheng's career spanned one of the most chaotic periods in Chinese history, his leadership was illustrated both by the respect he enjoyed among leading private sector entrepreneurs in Hong Kong and his close connections to the political system in Beijing. His affinity to the CCP was illustrated by his yearly attendance as a delegate at the National People's Congress in Beijing (Mingpao Yuekan, April 10, 1989). Zheng was also a close friend of the then Premier Zhou Enlai and reportedly dined with Zhou alone at Congress. Such closeness to senior CCP figures may explain the ability of the BOC to adapt quickly to new developments on the Mainland.

Following Zheng's retirement in 1966, the bank was managed by Li Choh-chi (李佐 治). Mr. Li enjoyed a similar political background. He guided the bank through the chaos of the Cultural Revolution and the sterling crisis of 1967, where the bank became the largest purchaser of sterling from HSBC. Despite deep political hostilities and a volatile environment, the Hong Kong management of the BOC were able to work with their counterparts in the international banks. The ability of the BOC to honour all deposits during this period and supply the increasing quantity of sterling required by the Mainland was testament to the management's ability to operate effectively under a hostile environment. Li died in 1974 (SCMP, September 18,1974). What distinguished this generation was that even though many had started their careers under the pre-1949 capitalist system, their sympathy for and loyalty to CCP values could be relied upon.

\section{Adapting to the Internationalisation of Finance}

The early 1970s witnessed a number of important developments in the domestic and international economy that changed the environment under which the BOC operated. The 
ending of the Bretton Woods' Gold Standard in 1971 increased the level of uncertainly in the international monetary environment. This was followed by an ending of the interest rate cartel, a move that led to a greater internationalisation of finance as banks were forced to compete with other deposit-taking institutions for finance. On the Chinese Mainland, the PRC's leadership had become more stable as many cadres purged during the early years of the Cultural Revolution were reinstated. A remarkable and often overlooked feature of this period is that Mainland banks in Hong Kong had already adapted to these changes before the launching of the Mainland's economic reforms in 1978.

These changes were quickly reflected in the BOC's operations. The bank began to employ financial innovations such as the use of deferred payments, trade credits and mutual deposit schemes. These were innovative in the sense that they allowed the PRC to finance the purchase of plant and machinery, without compromising on its ideological opposition to trade finance. Under the mutual deposit scheme, the BOC and other foreign banks would deposit funds with each other in their respective national currencies, with the foreign banks depositing more, essentially amounted to a de facto inter-bank loan (Jao, 1983). The BOC also began to actively promote the RMB as one of the few stable international currencies by offering non-deliverable RMB deposit accounts, with payment in Hong Kong currency on maturity based on the day's rate against the RMB. This is important for two reasons. The first is that it matched the PRC's ambition of having the RMB viewed as a stable alternative to the speculative currencies of the West and suitable for use in trade invoicing (Xinhua, September 21, 1974). The Chinese leadership viewed this as vital in removing perceived disadvantages in international trade. The second is that it put in place the institutional foundations for the process of RMB internationalisation. In another example of the continuity that has characterised Hong Kong's role as an internationalising force for the PRC's financial sector, 
in 2003, almost three decades later, the BOC's Hong Kong branch became the first designated clearing bank for RMB settlement.

The period after 1971 also marked a change in the BOC's strategy as it sought to increase its branch presence in Hong Kong. Between 1949 and 1972 the BOC had just one branch in Hong Kong. The transition to retail banking meant that the bank required a branch presence and from 1972 onwards the bank began to increase its branch numbers. By 1978 it had seven branches (HKRS 411-2-45(2)). The total number of PRC state-owned bank branches increased from 58 to 123 over the same period. This reflected an effort to rebuild branch-level trust among the business community and general public in Hong Kong following the chaos and disruption of the Cultural Revolution. It also reflected the need to compete more vigorously for deposits reflecting both the changes in bank funding internationally and the demands of funding the Mainland's modernisation. In October 1974 the $\mathrm{BOC}$ raised its six-month deposit rate to $7 \%$ compared to the previous rate of $4.5 \%$, going against the local trend of rate reductions (HKRS 70-6-91). Such innovations were a necessary prerequisite to putting in place the branch network and deposit base that allowed the BOC emerge as one of the major competitive threats to established Hong Kong banks such as HSBC (Goodstadt, 2005). However the scale of these innovations was too small to meet the demands of financing the PRC's post-1978 industrialisation.

\section{Ideological and Generational Change}

The role given by the post-1978 "open door" reforms to FDI made these innovations and the compromises they entailed almost redundant. The implication was that henceforward, banking standards were to be judged against the criteria set by pragmatism. In Hong Kong, PRC banks began substantial international borrowing at the same time as the government began to secure low interest loans from foreign lenders (Kueh and Howe, 1984). Continuing 
its tradition of innovation, the BOC pioneered the introduction of a number of products in foreign currency accounts and telephone banking as well as introducing mortgage finance in its Mainland branches (Sung, 2005). In 1994 it became the third note issuing bank in Hong Kong, along with HSBC and Standard Chartered. In 2002 the BOC became the first subsidiary of a Mainland state-owned bank to issue shares to the public on the Hong Kong stock exchange. After this, its PRC-based parent company the BOC retained indirect control of the BOC in Hong Kong by retaining $74 \%$ of its shares. By this stage the BOC had a leading positon in Hong Kong's retail, corporate and treasury banking (BOC, 2002).

However, this radical adjustment in the BOC's strategy carried a longer-term cost for the bank in terms of risk and professional standards. The bank's IPO prospectus published in 2002 revealed a catalogue of risk factors from a high exposure to risky property -based lending to misconduct by its staff and customers (BOC, 2002: 26-36; 168-69). In May 2003, the bank announced that its Chief Executive Liu Jinbao (刘金宝) had resigned and was being investigated for corrupt lending to a Shanghai property tycoon (BOC, 2003). In August 2004, two deputy chief executives were transferred to Beijing to be investigated by PRC authorities for allegedly misappropriating funds for personal use (The Standard, August 4, 2004). In 2008 the bank required a loan from its parent bank to shore up its capital base following write downs as a result of exposure to the US sub-prime market (SCMP, December 13, 2008).

The striking feature of these problems is that they involved such behaviour as speculative lending and the personal use of bank funds that was ethically forbidden pre-1978. They also concealed a discontinuity in the selection of senior management in the sense that it was no longer so easy to find staff with strong CCP credentials and whose loyalty to CCP values could be assumed. This meant that PRC banks invariably appointed candidates who were close to the CCP. Liu Mingkang (刘明康), the BOC's Hong Kong chief executive at the time of its IPO, was a vice-governor of the People's Bank of China and a vice-chairman of its 
monetary policy committee, a vice-governor of the of the State Development Bank of China, and a secretary-general of the Fujian provincial government (BOC, 2002: 192).

Although it is difficult to generalise the effects of generational change and discontinuity in management, the BOC's experience indicates that selection on the basis of political criteria no longer guaranteed loyalty to the national interest. The new generation of senior management, many of whom joined the BOC in the late 1970s (for example, Liu Jinbao in 1976 and Liu Mingkang in 1979,) could no longer publically claim moral distaste for capitalism. It is likely that this generation would have witnessed the discrediting of all sources of moral authority including education, family and state during the Cultural Revolution. In their professional life it meant that the choice of occupation was no longer based on self-sacrifice and idealism, but rather on self-advancement. However, although they operated in advanced capitalist economies, CCP remuneration practices and governance structures were not immediately abolished. The BOC was criticised for having far lower rates of remuneration that their Hong Kong peers. In 2003, while the BOC's CEO was paid HK\$2.5 million, the CEOs of the Bank of East Asia and Hang Seng Bank, two Hong Kong banks, were paid HK\$17.5 million and HK\$7.7 million respectively (CLSA, 2004: 51).

\section{PRAGMATISM, CONTINUITY AND VARIATION}

The role given to the BOC in Hong Kong during the years 1949-78 improved the PRC's ability to import plant and machinery during a period of great shortage. It also helped put in place the financial infrastructure and institutional continuity that has seen Hong Kong emerge as an internationalising force for Chinese business and finance. This article indicates that this role was initially underpinned by a unique generation of management. Their loyalty to communist beliefs and values distinguished them from their successors and enhanced their capacity to deal with the foreign exchange shortage faced by the PRC. However this does not 
fully explain why the BOC was permitted to conform to what were colonial and capitalist banking practices. One explanation is that the BOC's participation in this market reflects an often overlooked pragmatism within the PRC's leadership towards international finance. This pragmatism often took precedence over ideology in times of crisis. This was reflected in the BOC's response to the post-Great Leap famine and also in the ease at which it responded to changes in the international banking environment during the 1970s. It is also interesting that for much of the period covered by the article, management were essentially the same people recruited from the party elite. Economic reforms in 1978 altered the rules under which management operated. The paper indicates that although these changes vastly improved the capacity of the BOC's management to deal with commercial competition, their shortcoming was a decline in professional ethics as ideology gave way to commercial pragmatism.

This sense of pragmatism that characterised the BOC's Hong Kong operations is succinctly captured in Mao's own view expressed in 1949 that even the best ideology is only effective if it is linked with objective realities (Mao, 1949). The bank's pragmatic solutions to pressing economic shortage may also have paradoxically stemmed from ideological incoherence. Concealed within the high level of hegemony achieved by the CCP post-1949 was a lack of coherence (Shue, 1994). This meant that the party line could be reinterpreted to suit particular interests. This allowed the leadership to implement pragmatic economic solutions in clearing up the mess left by the Great Leap (Lieberthal, 1995). This was illustrated in the willingness of the leadership "to relax ideological remoulding in return for the active co-operation of non-communists" in dealing with economic crisis (MacFarquhar 1997, 240). For the BOC, such signals would have meant that innovative solutions to foreign exchange shortage were permitted so long as it was careful to avoid any behaviour, including trade in US\$, that might be considered illegal. Indeed most of what the BOC did resulted from administrative restrictions being applied loosely. This helps explain why, at times of 
severe shortage and economic crisis, the BOC was able to increase its participation in Hong Kong's financial markets. The ability of banks to cope with significant institutional variation is consistent with historical accounts of other large banks such as HSBC, which had a long history of working with the UK government (King, 1991). It is also consistent with Cheng's (2003) account of the development of Chinese banks between 1897 and 1937, which indicates that innovation was not a patent belonging exclusively to Western culture.

The ability to do this was also aided by the extraordinary continuity between the preand post-1949 management. This ensured institutional succession almost by voluntary association. A similar institutional continuity was evident after 1978, but the undermining of ideology and the emergence of a new generation of management meant that the link with CCP ideologies had been broken. This highlights an important link between continuity, management beliefs and organisational strategy. This is consistent with the literature on entrepreneurship which indicates that beyond the role of legal constructs, firms are designed to outlive people and when people change so too does the strategy of the frim (Casson, 2010). A changing environment alters and challenges the nature of administrative coordination (Penrose, 1954). Indeed in attempting to preserve continuity post-1978, the CCP tried to preserve "the core principle of CCP appointment of financial executives" (Heilmann 2005, 17). This principle also extended to the appointment of key overseas banking personnel but it was frustrated by a breakdown in the CCPs own hierarchies. This breakdown may help explain why the BOC's early adaptation to changes in the international financial system in the 1970s, did not translate into a faster opening-up of the PRC's banking system post-1978. Instead FDI became the major source of finance. Hong Kong and its neighbouring province, Guangdong, provided a medium for the spread of financial crises, highlighting the initial fragility of domestic institutions (Nolan, 2004). 
A direct comparison with the BOC's Mainland operations after 1978 lends support to Baumol's contention and its objective of identifying the most effective rules for entrepreneurship. It also shows that more stringent regulations on banking practices can mitigate financial contagion, even within the same organisation. An official audit of the BOC's Mainland operations covering the period 1992-2000 revealed some 22 incidents of suspected fraud or misconduct involving RMB 2.7 billion (BOC, 2002). Between 1993 and 2001 some US $\$ 500$ million (RMB 4.135 billion) in foreign exchange was suspected to have been embezzled from the BOC's Kaiping sub-branch in Guangdong Province. At the end of 2001, the BOC's mainland parent bank had some RMB 436 billion in Non Performing Loans (NPL)s on its books (BOC, 2001). Although many of these loans were policy driven, it is difficult to see how policy would override loan viability to such an extent if loans were issued strictly in accordance with policy guidance. It is also intuitive that the potential for inefficient investment and the danger of default is always likely to be higher in a system where loans are made on the basis of political connections rather than credit worthiness. The fact that the NPL problem did not spread to the BOC's Hong Kong branch illustrates the value of more stringent rules on bank behaviour in preventing contagion and in lifting professional standards more generally. It is plausible therefore that Hong Kong's stronger banking regulations had the effect of lessening the magnitude of institutional scandals that occurred in its Mainland operations.

The experiences of the BOC in Hong Kong were in many a forerunner of the changes that were later to take place in the Mainland's banking sector, particularly the lesser role banks were to play in financing economic growth. The innovations adopted by the BOC during the 1970s lacked the size and scope required to finance China's investment requirements. After 1978 a foreign exchange surplus, driven by large inflows of FDI, soon replaced the previous shortage. During the period 1979-82, China received US\$1.16 billion in 
FDI and \$10.7 billion in foreign loans (XZWNTZH, Table A57). Between 1978 and 1981 the share of bank loans in total credit declined from 99 to 90 per cent (XZWNTZH, A59). At the same time, the share of loans in GDP increased from 51 to $58 \%$ reflecting the entrance of foreign capital and the emergence of a range of non-bank financial institutions. A more subtle effect of this change was that the benefits of ideological integrity in foreign exchange were no longer quantifiable in hard currency. A surplus of FDI meant that the currency off-take trade were no longer necessary. In parallel, among the clients of state banks, party status and political connections were no longer so closely related to idealism but were used to access loans from state-owned banks, which could be rolled over indefinitely (Manion, 2004). That the BOC's Hong Kong operations remained largely untouched by the effects of such problems indicates that stronger rules and greater prudential supervision can play a part in mitigating the contagion of financial malpractices.

\section{CONCLUSION}

The reform of the PRC's banks in Hong Kong was in many ways a forerunner to banking reform in Mainland China. Nowhere is this more apparent than in the transition of the Hong Kong branch of the BOC from the PRC's overseas foreign exchange branch to a legally separate and commercially minded entity as part of the BOC group. The paper has shown that a feature of this transition was a remarkable level of continuity. This spanned the BOC's transition from private to communist ownership in 1949; to its role during the period 1949 to 1978; and its later appointment as an international clearing bank for the RMB in 2003. This was underpinned by a high level of management continuity and facilitated by a remarkable level of economic pragmatism. This enabled management to correctly interpret changes in the domestic and international economies. It was further illustrated in the ease at which the BOC could resolve the compromises surrounding participation in capitalist markets between 1949 
and 1978. These innovations were by themselves not enough to finance China's post-1978 economic modernisation. The switch to a pragmatic growth model after 1978 offered PRC financial institutions an appealing solution to shortage and bureaucratisation, but it also radically altered the rules under which banks operated. Prior to 1978 it was assumed that bank behaviour would be virtuous, so long as it was subject to the CCP's moral authority. After1978 the assumption that banks would behave virtuously no longer held. Yet, it is notable that the Hong Kong branch of the BOC did not suffer the same level of professional deterioration as its Mainland parent. The implication is that regulatory supervision and stricter rules on behaviour have the potential to mitigate the contagion of poor governance practices, even within the affiliates of international banking organisations.

There are important caveats to the findings of this paper. Although every care has been taken to verify the events described in this paper with other publications and participants, the narrative refers to one part of the PRC's financial system and relies on a limited range of sources. The BOC was one of the few PRC entities to operate in international markets during this period. The availability of new archival material would shed greater light on the role of PRC banks in financing China's pre and post-1978 industrialisation. The challenge of finding management in the financial sector whose ethical beliefs are consistent with those of society is in no way unique to China and the status of banking as profession more generally has been undermined by malpractices in the lead up to the recent Global Financial Crisis. Correcting these issues has arguably been made more difficult by a homogenisation of behaviour in the banking profession. This has coincided with a departure from the ideological, political, mutual and religious principles that have previously underpinned behaviour and differentiated banking practices across different countries. 


\section{Acknowledgements}

The author would like to acknowledge the helpful assistance of staff at the Hong Kong Public Records Office in assisting this research and the comments of anonymous referees. The author would also like to acknowledge the helpful suggestions of the editor in preparing this manuscript for publication. 


\section{REFERENCES}

Allen, F., J. Qian, and M. Qian. 2005. "Law, Finance and Economic Growth in China.” Journal of Financial Economics 77: 57-116.

Baumol, W. 1990. "Entrepreneurship: productive, unproductive and destructive." Journal of Political Economy 98: 893-921.

Bank of China. 2001. Annual Financial Report. Beijing: Bank of China.

Bank of China Hong Kong Limited. 2002. Global Offering Prospectus 6 July 2002.

Bank of China Hong Kong Limited. 2003. Change of Chairman and Chief Executive 28 May 2003.

Casson, M. 2010. "Entrepreneurship: theory, institutions and history.” Scandinavian Economic History Review 58: 139-170.

Cetina K., and U. Bruegger. 2002. "Global microstructures: the virtual societies of financial markets." The American Journal of Sociology 101(4): 905-950.

Cheng, C. 1954. Monetary Affairs of Communist China. Hong Kong: Union Research Institute

Cheng, L. 2003. Banking in Modern China. Cambridge: Cambridge University Press

Chou, C. 1978. "Bank of China and the settlements of international payments." In China's Foreign Trade and Its Management, 97-105. Hong Kong: Chung Hwa.

CLSA. 2004. "Corporate Governance in Asia: Spreading the Word, Changing rules in Asia" CLSA September 2004.

Deng, X. 1978. "The working class should make outstanding contributions to the four modernisations" Speech at the Ninth National Congress of Chinese Trade Unions, 11 October 1978.

Donnithorne, A. 1967. China's Economic System. London: Allen and Unwin 
Goodstadt, L. 2005. Uneasy partners: the conflict between public interest and private profit in Hong Kong. Hong Kong: Hong Kong University Press.

Goodstadt, L. 2007. Profits, politics and panics: Hong Kong's banks and the making of an economic miracle, 1935-1985. Hong Kong: Hong Kong University Press.

Hale, G., and C. Long. 2010. "What are the Sources of Financing of the Chinese Firms?" Hong Kong Institute of Monetary Research Working Paper. 19/2010

Heilmann, S. 2005. "Regulatory innovation by Leninist means: communist party supervision in China's financial industry." China Quarterly 181: 1-21

Hong Kong Records Service (HKRS) 163-1-3274 "Chinese Mainland Banks”.

HKRS 163-1-625 "Banking Statistics and Collection of."

HKRS 934-7-104 "Notes on Deacon T.K Chiu”

HKRS 156-1-4850 "Worker Housing Schemes"

HKRS 163-1-735 "Correspondence regarding the modification and design of the BOC building"

HKRS 411-2-45(2) "Branch Numbers Compared"

HKRS 70-6-91 "Banks and Banking"

HKRS41-1-8569 "Tolerance of Chinese Banks"

Hong Kong Review of Overseas Trade. 1978. Hong Kong: Census and Statistics Department. Jao, Y. 1974. Banking and Currency in Hong Kong: A study of post-war financial development. London: MacMillan

Jao, Y. 1983. "Hong Kong's Role in Financing China's Modernisation.” In China and Hong Kong: The Economic Nexus, edited by A.J. Youngston, 14-67. Hong Kong: Oxford University Press.

King, F. 1991. The History of the Hong Kong and Shanghai Banking Corporation Vol. IV. Cambridge: Cambridge University Press 
Klein, D. 1960. “Peking's evolving ministry of foreign affairs." China Quarterly 4: 28-39.

Kueh, Y. and C. Howe. 1984. "China's international trade: policy and organisational change and their place in the economic adjustment." China Quarterly 100: 813-848.

Lardy, N. 1977. Chinese Economic Planning. New York: M.E. Sharpe.

Lardy, N. 1998. China's Unfinished Economic Revolution. Washington: Brookings

Levine, R. 1997. "Financial Development and Economic Growth: Views and Agenda." Journal of Economic Literature 35: 688-726.

Lieberthal, K. 1995. Governing China: From revolution through reform. New York: W. W. Norton.

MacFarquhar, R. 1997. The Origins of the Cultural Revolution, Volume 3: The Coming of the Cataclysm, 1961-1966. Oxford: Oxford University Press.

Manion, M. 2004. Corruption by Design: Building Clean Government in Mainland China and Hong Kong. Cambridge: Harvard University Press.

Mao, Z. 1949. Selected Works of Mao Zedong. Beijing: Foreign Language Press.

Mingpao Yuekan [Mingpao Monthly]. 1989. "Eighty Years of National Affairs that Touched on my Life," 227, January 1989: 29-35.

Nolan, P. 2004. China at the Crossroads. Cambridge: Polity

Penrose, E. 1954. The Theory of the Growth of the Firm, Oxford: Oxford University Press.

Reardon, L. 2002. The Reluctant Dragon: Crisis Cycles in Chinese Foreign Economic Policy. Seattle: University of Washington Press

Schenk, C. 2002. "Banks and the emergence of Hong Kong as an international financial center." Journal of International Financial Markets, Institutions and Money 12, 321-40.

Schenk, C. 2009a. "The Banking and Financial Impact of the 1967 riots in Hong Kong.” In May Days in Hong Kong Emergency and Riot in 1967, edited by R. Bickers and R. Yep, 105-26. Hong Kong: Hong Kong University Press. 
Schenk, C. 2009b. Banking and Exchange Rate Relations between Hong Kong and Mainland China in Historical Perspective: 1965-75" in Hong Kong SAR's Monetary and Exchange Rate Challenges, edited by C. Schenk, 45-72. Basingstoke: Palgrave.

Shue, V. 1991. "Powers of State, Paradoxes of Dominion" In. Perspectives on modern China: Four anniversaries, edited by K. Lieberthal, 205-225. London: M.E. Sharpe.

Stiglitz, J. 1989. "Financial Markets and Development." Oxford review of Economic Policy 5(4): 55-68.

Sun, C. 1957. "Shangye jihua biao [Commercial Planning Tables]." Jingji Jihua [Economic Planning] 2: 27-31.

Sung, Y. 2005, The Emergence of Greater China. Basingstoke: Palgrave Macmillan

Tobin, D. 2011. “Austerity and Moral Compromise: Lessons from the Development of China’s Banking System.” World Development, 39(5): 700-11.

United States Homeland Security and Government Affairs Committee. 2012. "HSBC Exposed US Financial System to Money Laundering, Drug Terrorist and Financing Risks" Report. $16^{\text {th }}$ July 2012.

XZWNTZH. 1999. Xin Zhongguo Wushi Nian Tongji Ziliao Huibian (XZWNTZH)

[Comprehensive Statistical Data and Materials on 50 Years of New China].. Beijing: Zhongguo Tongji Chubanshe.

Xinhua [New China News Agency] "PRC remains free of inflation, Currency stable" $21^{\text {st }}$ September 1974

Xinhua. 1974. "Many US, W European Banks in Financial Straits” 24 October 1974.

Xinhua. 1976. "Soviet's Materialisation of Détente viewed” 1 March 1976

Yeh, W. 1995. “Corporate Space Communal Time: Everyday Life in Shanghai’s Bank of China." American Historical Review 100: 97-101 
Zhang, Y. 1984 "Setting up Organisations of State Power at Basic Level." Beijing Review 23: $22-23$ 


\section{NOTES}

${ }^{1}$ Police concerns are recorded in HKRS156-1-4850 Workers Housing Schemes.

${ }^{2}$ The accusations were set out in a letter received by the Far East Bank on June 23, 1967 titled 'Letter from all Staff and Workers at the Bank of Communications Hong Kong Branch to the Staff and Workers at the Far East Bank'.

${ }^{3}$ Such concerns were outlined in a series of memos between the colonial secretary in the UK and officials in Hong Kong recorded in "Tolerance of Chinese Banks" HKRS41-1-8569.

${ }^{4}$ The working relationship of HSBC and Standard Chartered with the BOC was described as “close and friendly" See Record: CO 1030/609 "Singapore. Relations with China."

${ }^{5}$ A detailed search of all public and media records in Hong Kong for the period uncovered only one case of alleged impropriety. The case, reported in the Hong Kong Star ('Red Bankers go to Canton for Cash Quiz, November 22, 1969), alleged that the then manager of the BOC fled Hong Kong for Macao to meet a senior cadre from Canton. A detailed search indicated no evidence to support the story.

${ }^{6}$ See "Telegram from Secretary of State for the Colonies to Officer administering Government of Singapore” January 19, 1958. Record No. CO 1030/609: “Singapore. Relations with China." 
